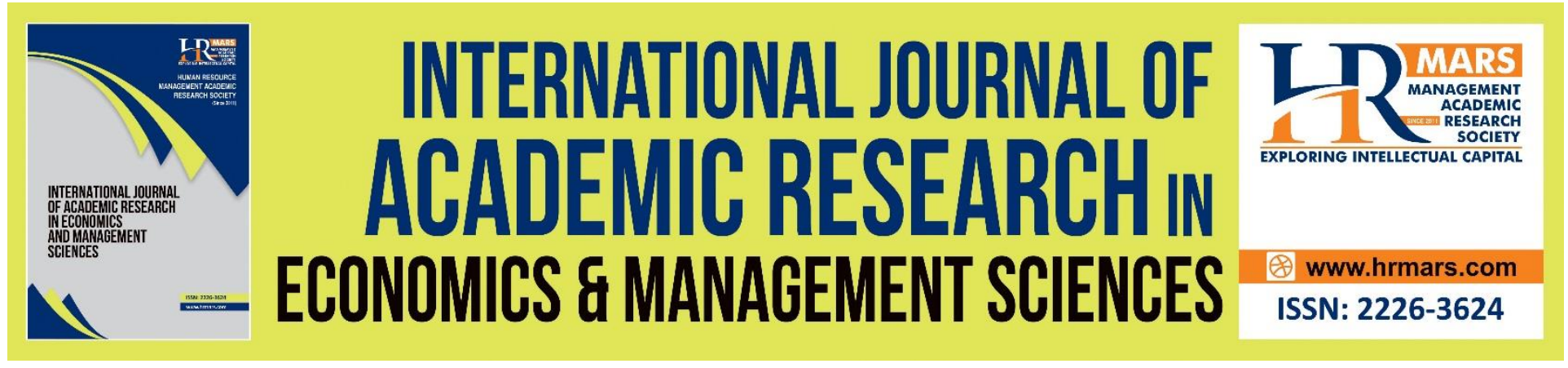

\title{
Systematic Literature Review of Higher Education and Unemployment in Asian Countries
}

Nur Sheilla Saida Abdullah, Mohamad Zuber Abd. Majid \& Muhammad Hussin

To Link this Article: http://dx.doi.org/10.6007/IJAREMS/v11-i1/12141

DOI:10.6007/IJAREMS/v11-i1/12141

Received: 11 November 2021, Revised: 19 December 2021, Accepted: 30 December 2021

Published Online: 17 January 2022

In-Text Citation: (Abdullah et al., 2022)

To Cite this Article: Abdullah, N. S. S., Majid, M. Z. A., \& Hussin, M. (2022). Systematic Literature Review of Higher Education and Unemployment in Asian Countries. International Journal of Academic Research in Economics and Management and Sciences, 11(1), 70-91.

Copyright: (c) 2022 The Author(s)

Published by Human Resource Management Academic Research Society (www.hrmars.com)

This article is published under the Creative Commons Attribution (CC BY 4.0) license. Anyone may reproduce, distribute, translate and create derivative works of this article (for both commercial and non-commercial purposes), subject to full attribution to the original publication and authors. The full terms of this license may be seen

at: http://creativecommons.org/licences/by/4.0/legalcode

Vol. 11, No. 1, 2021, Pg. 70 - 91 


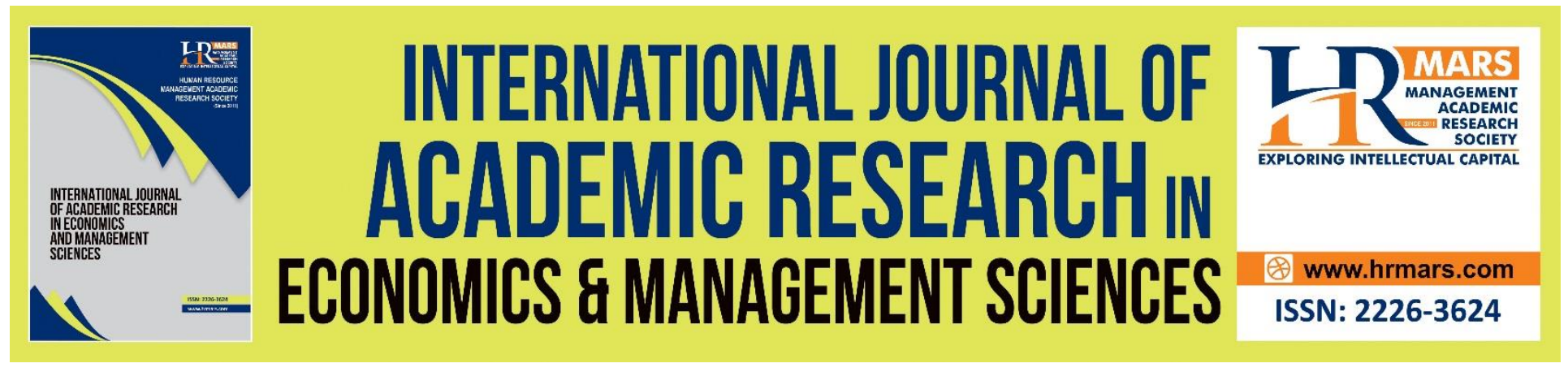

\title{
Systematic Literature Review of Higher Education and Unemployment in Asian Countries
}

\author{
Nur Sheilla Saida Abdullah, Mohamad Zuber Abd. Majid \& \\ Muhammad Hussin
}

Faculty of Education, Universiti Kebangsaan Malaysia, Bangi, Selangor, Malaysia.

Email: P112830@siswa.ukm.edu.my,mzuber@ukm.edu.my, muhsin@ukm.edu.my

\begin{abstract}
A systematic literature review on higher education and unemployment in Asian countries is presented in this paper. It analyses the themes emerging from 31 articles identified through Scopus and the Web of Science database. The review was conducted using the Preferred Reporting Items for Systematic Reviews (PRISMA) approach which provides a comprehensive guideline for systematic review and data collection. The review included research studies published between 2018-2022. Students' expectations, the job market and economics, and education, experience, and skill development were the three categories for the themes. These topics are discussed in depth in this paper and are presented in the literature review. Rather than reiterating the literature review and acknowledging the problem, an approach with a focus on innovative solutions to bridge a gap between graduates, employers, and academic expectations were also presented. This study found that higher education institutions focus on strategies to accelerate graduate competency development to ensure employability. Moreover, in Asian countries, graduate employability is grounded on a strong sense of innovation, collaboration efforts, and government intervention for sustainable economic growth.
\end{abstract}

Keywords: Higher Education, Graduates, Unemployment, Employment, SLR

\section{Introduction}

Enrolment in higher education has risen steadily in Asia in recent years. Higher education institutions (HEls) play a critical role in producing knowledgeable and skilled graduates that can lead national development. In this regard, empowering higher education has become a national strategy to increase competitiveness in the global market as they are considered repositories of significant human capital to assist local and global development. HEIs enrolment has increased from 23.8 million in 2015 to 25.5 million in 2020. This reflects the global push to develop a knowledge-based economy (UNESCO, 2022). The increase of enrolment has pushed HEls to build more campuses, employ new academic and nonacademic staff and welcome more private higher education providers. Such education investments will be fruitful when there is an equilibrium between universities' programme and industry requirements, where graduates' theoretical knowledge and on-the-job training could be utilised efficiently in the labour market. 
Regrettably, unemployment among university graduates has become a serious issue. In recent years, Asia has been plagued with high unemployment rates as graduates struggle to find employment. According to International Labour Organization (ILO, 2019), unemployment among young graduates in this region has risen from 14.2 percent in 2018 compared to 12.7 percent in 2012. Recent graduates have to face a highly competitive job environment. The limited job options available forced graduates to choose between idealism and realism; either settle for a less than suitable job or become one of the many intellectually unemployed individuals. The mismatch between skills and employment could contribute to low productivity in the workforce. In this regard, employees whose job does not aligned with skilled might be less productive that those working in jobs which require them to fully utilise their skills. Furthermore, mismatched personnel may demonstrate counterproductive behaviour on the job due to job discontent, such as higher absenteeism and high turnover intention (Somers et.al 2019).

The systematic literature review reported in this paper is grounded on the relationship between higher education and unemployment, specifically in Asian countries subject of paper. The review will examine how aspects like graduate experience knowledge, expectations, skill development, and the current job market climate and economy impact graduate unemployment. This review will fill in the gap in research on higher education and employment in the Asian region. Furthermore, current systematic review studies on the topic do not elaborate on the review approaches including keyword identification, article screening, and article eligibility. As a result, prospective researchers are unable to replicate the review, verify the interpretation, or determine the range of data covered by these reviews. This research is also significant because it helps researchers understand the peer literature reviews which could help them between understanding of unemployment challenges faced by graduates with high academic qualifications. The current systematic analysis corresponds to the main research question, "What are the attribute characteristics that make our graduates employable?" Aside from that, this section discusses the need for a comprehensive review of graduates' job prospects. Meanwhile, the proceeding section details the approaches employed to answer the research question addressed by the current report. The next section describes the process in conducting systematic review and synthesis of the scientific literature employed to ascertain, select, and analyse necessary studies conducted in the Asian context. The last section suggests actions and changes to improve higher education programmes to create a balance between employability and academic qualifications. Suggestions and recommendations for future research are also presented.

\section{Material and Methods}

There is an abundant of systematic reviews conducted worldwide. In contrast, there is a lack of systematic reviews on the mismatch between employability and academic qualification in the Asian context. Thus, this study adopted the PRISMA method to conduct the systematic literature review.

\section{Identification}

The first step in the systematic review is to identify suitable publications for the review. First, the researchers determined the keywords and related or similar terms using dictionaries, encyclopaedia, thesaurus, and previous works. After the identifying the important terms, the researcher have created search strings as shown in Table 2 for searching the articles in the 
Scopus and WOS databases. The researcher successfully retrieved materials from both databases.

\section{TABLE 2}

\section{The Search Strings}

$\begin{array}{llr} & & \\ & \text { TITLE (higher AND education OR tertiary AND education OR } & \text { graduate } \\ \text { AND unemployment OR employment) AND (LIMIT TO (PUBSTAGE, "final”)) } \\ \text { Scopus } & \text { TO AND (LIMIT TO (OA, "all")) AND } \\ & \text { (LIMIT-TO (PUBYEAR, 2021) ORLIMIT-TO (DOCTYPE, "ar")) - } \quad \text { (LIMIT TO } \\ & (\text { LANGUAGE, "English")) AND (LIMIT TO (SRCTYPE, "j")) }\end{array}$

Web of higher AND education [Title] OR tertiary AND education [Title] OR graduate Science [Title] AND unemployment [Title] OR employment [Title] AND (2021 [Filter])

\section{Screening}

The screening phase started by identifying and excluding duplicate articles. Ten articles were excluded during the first round of screening. Then, the remaining articles were evaluated to determine whether they fit the inclusion criteria, which is the articles should report findings of research studies as they are the primary source of practical information. Consequently, articles that present findings of meta-analyses, systematic reviews, article reviews, metasynthesis, book series, book volumes, book chapters, or conference proceedings were excluded. Moreover, the articles should be written in English and published between 2018 and 2022. Lastly, only studies conducted in Asia countries were included to meet the analytic goal. Based on the researchers' inclusion and exclusion criteria, further 48 articles were excluded from the review.

\section{Eligibility}

The third step was conducted to determine the eligibility of articles derived for the review. The remaining 33 articles underwent a review of their titles and key contents. This step was conducted to ensure that the articles retained meet the inclusion requirements to fulfil the research objectives. 


\section{SCIENCES}

Vol. 11, No. 1, 2022, E-ISSN: 2226-3624 @ 2022 HRMARS

\section{TABLE 3}

The Inclusion and Exclusion criteria

\begin{tabular}{|c|c|c|}
\hline Criterion & Inclusion & Exclusion \\
\hline Language & English & Non-English \\
\hline Timeline & 2018 & $<2022$ \\
\hline Literature type & Journal (only research articles) & $\begin{array}{l}\text { Journal (book chapter, } \\
\text { conference proceeding) }\end{array}$ \\
\hline Subject Area & SS, B, E, AH & Besides SS, B, E, AH \\
\hline Countries & Asian only & Besides Asian \\
\hline
\end{tabular}

\section{Data Abstraction and Analysis}

An inductive thematic analysis (Braun \& Clarke, 2006) was used to identify relevant themes. The analysis yielded three primary themes spanning three broad thematic areas: graduate expectations, graduate knowledge, experience, and skills development, and job market and economy. There were six steps in this process: data familiarisation, data coding, identifying themes, reviewing themes, defining and labelling themes, and reporting the findings.

\section{Result and Finding}

Asian countries have rapidly increased the numbers of students attending university in recent years. However, the number of unemployed graduates is also rising significantly. Therefore, Asian countries need to focus not just on expanding higher education but also ensuring quality at the same time if graduate unemployment is to be contained. Based on the searching technique, 32 articles were extracted and analysed. All articles were categorised based on three main themes, which are graduate expectations and knowledge, ( 5 articles), experience and skills development, (15 articles), and job market and economics (10 articles). (Refer Table 4). 
INTERNATIONAL JOURNAL OF ACADEMIC RESEARCH ECONOMICS AND MANAGEMENT SCIENCES

Vol. 11, No. 1, 2022, E-ISSN: 2226-3624 ㄷ 2022 HRMARS
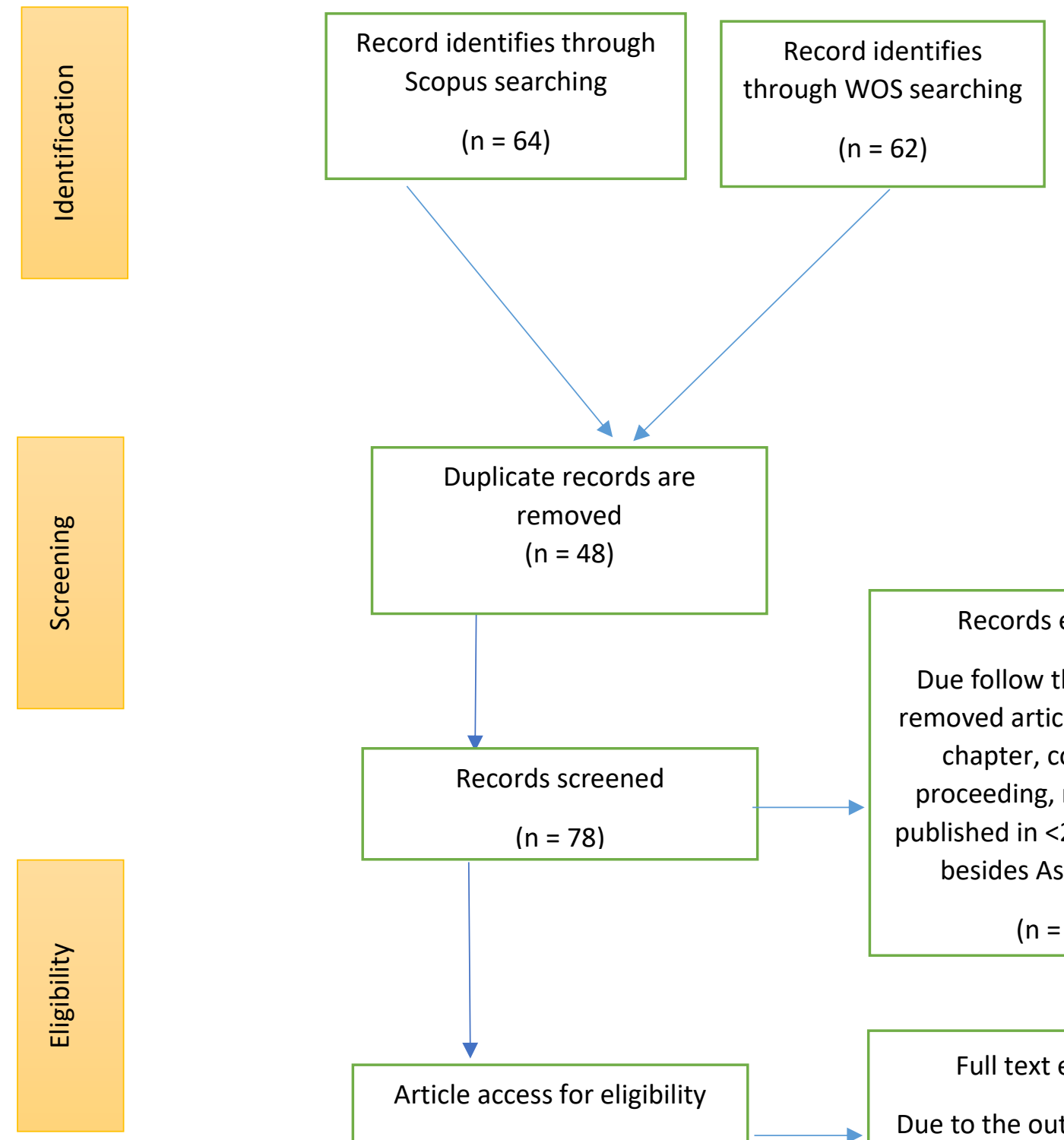

\section{Records excluded}

Due follow the criterion; removed article book, book chapter, conference proceeding, non-English, published in $<2018$ Non-and besides Asia country

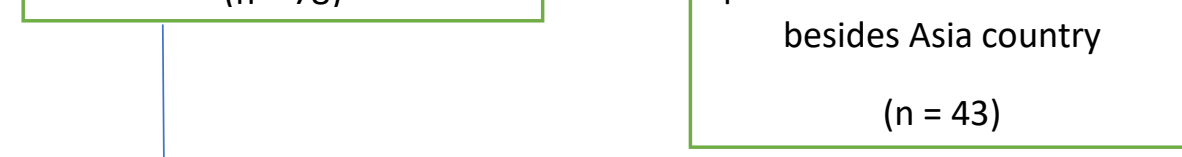

Full text excluded

Article access for eligibility

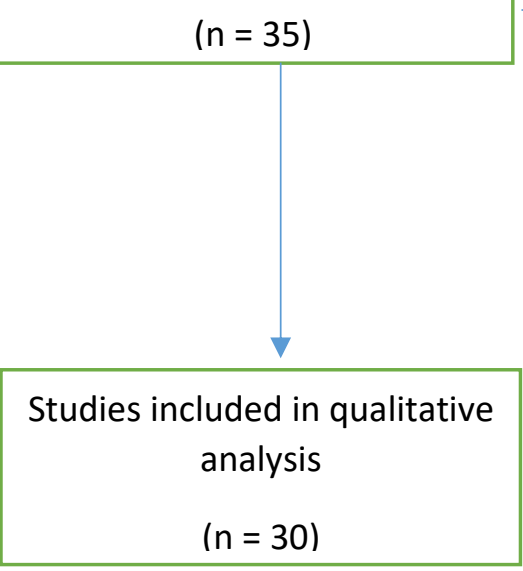

Due to the out of topic field

$$
(n=5)
$$

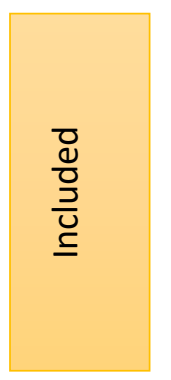

Figure 2. Flow Diagram of the proposed searching study (Moher et. al., 2009) 
INTERNATIONAL JOURNAL OF ACADEMIC RESEARCH ECONOMICS AND MANAGEMENT SCIENCES

Vol. 11, No. 1, 2022, E-ISSN: 2226-3624 @ 2022 HRMARS

\section{TABLE 4}

Finding based on the Search Criteria

\begin{tabular}{|c|c|c|c|c|c|c|c|}
\hline NO & Author & Year & Journal & Scopus & wos & Country & Remarks \\
\hline 1. & $\begin{array}{l}\text { Khan, } \\
\text { Hemsley- } \\
\text { Brown, }\end{array}$ & 2021 & $\begin{array}{l}\text { Journal of Marketing } \\
\text { for Higher Education } \\
1-24 \text {. }\end{array}$ & $\begin{array}{l}\text { Student satisfaction: the role of } \\
\text { expectations in mitigating the pain } \\
\text { of paying fees. }\end{array}$ & / & China & Graduate Expectations \\
\hline 2. & Chen \& Chen, & 2021 & $\begin{array}{ll}\text { International } & \text { Journal } \\
\text { of Financial } & \text { Studies } \\
9(3), 1-12 & \end{array}$ & $\begin{array}{l}\text { The Impact of Higher Education } \\
\text { Expansion on the Educational Wage } \\
\text { Premium in Taiwan: } 1985 \text { to } 2015 \text {. }\end{array}$ & / & Taiwan & Graduate Expectations \\
\hline 3. & $\begin{array}{l}\text { Yoon, Park, \& } \\
\text { Kim, }\end{array}$ & 2020 & $\begin{array}{l}\text { Sustainability } \\
\text { (Switzerland) } \\
12(8), 1-10\end{array}$ & $\begin{array}{l}\text { Assessing the effects of higher- / } \\
\text { education factors on the job } \\
\text { satisfaction of engineering } \\
\text { graduates in Korea. }\end{array}$ & & Korea & Graduate Expectations \\
\hline 4. & Lim \& Lee, & 2018 & Journal for Labour & Exit duration and unemployment & / & Korea & Graduate Expectations \\
\hline
\end{tabular}


5. Samarakoon, 2018 Sri Lanka Journal of An exploratory study on low labour SJMNG.,

Mayadunne, Social 41(2), 137-151. Sciences force participation of women in Sri Lanka.

6. Maneejuk, Yamaka, 2 Sustainability

$$
0 \text { (Switzerland) }
$$$$
2 \text { 13(2), 1-28. }
$$

1

7. Zheng, Zhang \& Zhu, 2 China

Economic Overeducation, major mismatch, and 0 Review 66, 1-14.

2

1

8. Aman
2 Sustainability
0 (Switzerland)
2 13(1), 1-11.
1

The impact of higher education on / economic growth in asean-5 countries. return to higher education tiers: Evidence from novel data source of a major online recruitment platform in China.

Sustainability of impact sourcing / initiatives in higher education for graduates' employability.
ASEAN

\section{Job market and economics}

/ China

Job market and economics

Malaysia Job market and economics
9. Choi, Choi \& Son,

\begin{abstract}
2 Labour 0 67, 1-17.$$
2
$$

The long-term effects of labor market entry in a recession: Evidence from the Asian financial crisis.
\end{abstract}$$
1
$$ 
10. Trisnaningsih, et al

2 Journal of Asian Contingency Model to Increase the 0 Finance Economics Uptake of Higher Education Graduates

2 and Business 7(4), 197- in the Job Market

0203.

12. Zhang \& Wang,
Open Factors Influencing Employment Rate and Mobility of Science and Engineering and Economics and Management Graduates in Northeast China: An Examination
/ Indonesia Job market and economics

/ China Job market and economics

/ Korea

Job market and economics
2 Annals of The Changes in Early Labor Market 0 American Academy of Outcomes among Young College

2 Political and Social Graduates in South Korea

0 Science

(1), 115-136.

14. Wang, et al
2 Sustainability
0 (Switzerland)
2 12(2), 1-14
0

15. Peng et al
Returns to education in different job / locations for off-farm wage employment: Evidence from China
China Job market and economics
/ Hong Kong
Job market and economics

\begin{abstract}
2 Social Returns to Education in Hong Kong: A
1143 (1), 133-156. Developed Society with High Economic Inequality
9


16. Chen \& Gan $\begin{array}{ll}2 & \text { Sustainability } \\ 0 & \text { (Switzerland) } \\ 2 & 13(23), 1-14\end{array}$ 1

17. Huang et al

19. Zhou et al.,

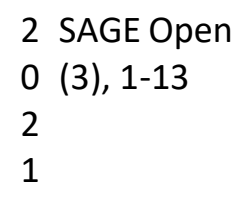

20. Lu et al

$$
\begin{array}{ll}
2 & \text { Sustainability } \\
0 & \text { (Switzerland) } \\
2 & 13(6), 1-25
\end{array}
$$$$
1
$$

21. Herlambang et al
Sustainable development of / employability of university students based on participation in the internship promotion programme of Zhejiang Province entrepreneurial? Causal evidence from China

Open Entrepreneurial Intention in Higher Vocational Education: An Empirically Based Model with Implications for the Entrepreneurial Community

11 Does College Education Promote Entrepreneurship Education in China?

How university entrepreneurship /
support affects college students'
entrepreneurial intentions: An
empirical analysis from China

Quality assurance for sustainable higher / education: Structural equation
/ China

Knowledge, experience and skills development

Knowledge, experience and skills development

Knowledge, experience and skills development Knowledge, experience and
skills development 


\section{13(9), 1-14. \\ modeling}

22. Mei et al

2 Education

Sciences $010(9), 1-18$

2

0

23. Yuan et al.,

2 Sustainability

0 (Switzerland)

$212(4), 1-15$

0

24. Mubarak et al.,

2 Career Dev

2 25(6), 671-690

0

25. Bai et al.,

2 Sustainability

0 (Switzerland)

2 (5), 1-20

0

26. Huang \& Hsieh,

2 Sustainability

2 12(5), 1-16

0
Entrepreneurship education and students' entrepreneurial intention in

higher education.

An empirical comparison of graduate / entrepreneurs and graduate employees based on graduate entrepreneurship education and career development.

The impact of high-performance human resource practices on the research performance and career success of academics in Saudi Arabia

Influencing factors for the promotion of /

12 international vocational qualification and certification: Evidence from international project manager professionals in China.

Interdisciplinary research on students' employability in technology education to advance higher education enrollment sustainability
China Knowledge, experience and skills development

China

Knowledge, experience and skills development

Saudi Knowledge, experience and Arabia skills development

China

Knowledge, experience and skills development

China
Knowledge, experience and skills development 
27. Hsieh \& Usak,

2 Revista de Cercet

0 Interventie

Sociala

High education radical transformation

2 68, 95-112

era: How teachers' competency can

0

28. Kamaruddin Mauzud,

\& 2 Geografia Malaysian Exploring The Ecological Assets of Tunas 0 Journal of Society \& Mekar Project's Graduate

1 Space

15 Entrepreneurs

9 (4), 288-303.

29. Baek, Cho \& Kim,
2 Inzinerine Ekonomika -
Convergence in Education and
0 Engineering Economics
130 (1), 59-68.
Employment of Engineering Students:

9

30. Baek, \& Cho,
2 Sustainability
0 (Switzerland)
1 (5), 1-20.
8

Identifying the virtuous circle of /

12 humanity education and post-graduate

employment: Evidence from a

Confucian country
Taiwan

Knowledge, experience and skills development

/ Malaysia Knowledge, experience and skills development

/ Korea

Knowledge, experience and skills development

China

Knowledge, experience and skills development 


\section{Themes}

\section{Graduate Expectations}

Higher education cultivates and accumulates human capital in many Asian countries. Higher education is deemed as the main driver of for economic growth, which has led to the influx in higher of education providers. It could be argued that the growth in higher education may not necessarily increase human capital in the short time period, but rather, depreciate the value of academic qualification A Taiwanese study by (Chen and Chen, 2021) reported that while Taiwanese government enforced highly regulated higher education policies which strictly control universities and students to avoid overinvestment and dilution of resources which have a negative impact on educational quality, it has shifted to a more open policy in the mid1990s. This shift has caused the increase in the number of Taiwanese universities, from 50 in 1995 to 150 in 2005. While the high number of graduates led to the increase of skilled labour supply, recent university graduates receive $12 \%$ to $21 \%$ lower salary their older counterparts. In the meantime, Lee (2021), posited that in Asian communities like in Taiwan, education is deemed as a way to eradicate poverty and promote social mobility. However, despite the large number of universities in Taiwan, there is still a wide gap in access to educational resources which results in a large disparity between rural/urban academic ability and opportunity.Therefore, multiple counselling mechanisms such as career counselling arranged by universities, will improve their academic achievement and also enhance their employability opportunities. Student expectations and student choice have a direct impact in choosing a higher education institution. The role of employability perceptions in mediating the relationship between study costs and student satisfaction, as well as the outcome (Khan \& Hemsley, 2021). Students' perceptions of employability after graduation mediate the relationship between the cost of study and the likelihood of making a recommendation to peers, and students' expectations of choice factors.

The rate of completion of tertiary education among young people in Korea was $69.8 \%$ in 2019 , ranking second among the Organization for Economic Co-operation and Development (OECD) countries. Unfortunately, graduates experience difficulties in finding a job. Youth unemployment rate in Korea increased 0.9\% from 2009 to 2019, (Korea Economic Research Institute,2020). These situations lead the universities to make an effort to solve the problem of youth unemployment by developing various employment support programs to improve student career development and employment capabilities. Research was conducted by $\mathrm{Na}$ and Lee (2021) to analyse employment support programs that should be prioritized for hospitality undergraduate students in Korea. Results showed that employment support programmes to be given top priority varied depending on the school year of the students. University employment support programmes must continue to identify and support students' needs. This research will assist university employment support programmes more effectively while also improving students' job placement performance in the labour market.

Unemployment among young people in Korea is a big concern. Lim and Lee (2018) investigated the influence of individual and college characteristics, employment preparation behaviour, self-esteem, and job searching activities in universities on lowering unemployment among graduates. The study found that individual and college variables influence how college graduates approach job search preparation. In the meantime, women place a greater emphasis on maintaining a good grade point average while men are more active in their job search than women. The longer a college graduate remains unemployed, the more difficult it is for him or her to obtain a job. 
SCIENCES

Vol. 11, No. 1, 2022, E-ISSN: 2226-3624 @ 2022 HRMARS

Lastly, self-esteem is an important aspect in boosting one's job prospects. Yoon, Park and Kim (2020) examined the link between elements in higher education and employment satisfaction among engineering graduates in Korea. Personal information, satisfaction with highereducation quality, and involvement in career development programmes are the three types of education variables. Internships are also more effective in increasing work satisfaction than short-term activities like job camps interviews and resume coaching. Despite gender parity in education which favours females and positive female education outcomes in Sri Lanka, nearly two-thirds of working-age women do not engage in the labour field and prefer to stay at home. Maternal status, religious identification, or labour market conditions have little effect on women graduates involvement in the work market.

The quantitative analysis shows that the low percentage of women with tertiary education stay at home because of availability of opportunities for employment at their expected wage levels. Samarakoon and Mayadunne (2018) suggest that, to encourage women to participate in the labour force, diversification of vocational training focusing on current and future demands in the job market, expansion for vocational training intakes, development of soft skills training facilities and development of career guidance are key areas requiring and urgent interventions.

\section{Job Market and Economics}

Over the last two decades, China's higher education sector has grown tenfold. More than half of the online job searchers have graduated for more than two years, resulting in a 5.1 percent salary penalty. Zheng, Zhang and Zhu (2021) argued the effect of overeducation on salary varies greatly depending on the quality of the institution, the kind of city, and the match between college major with industry. University graduates with degrees in STEM (Science, Technology, Engineering, and Mathematics) or LEM (Law, Economics, and Management) are the most overeducated and earn a considerable pay premium. In this regard, the mismatch between supply and demand can cause major imbalances with far-reaching effects for both individuals and the country.

Wang et. al (2020) used nationally representative samples from rural China to investigate the returns to education in different job locations for off-farm wage employment. Within the rural labour force, there are differences in the returns to education across work locations. Returns on education are much higher for workers in large cities than for workers in smaller areas. The youth unemployment rate in South Korea has increased considerably from 6.6 percent in 2002 to 9.8 percent in 2016. In contrast, the college acceptance rate remains above $70 \%$, and skill mismatch among college students is a serious policy problem. There has been little attention given to the difference in college graduates' labour market over time, or to the categories of graduates exposed to labour market uncertainty. Using data from the Graduate Occupational Mobility Survey's nine graduating cohorts, (Choi and Bae 2020) examined how college graduates' labour market experiences have altered over time. The findings show that the proportion of those looking for work has risen over time, and that employment quality has deteriorated even among those who are working. We also discover a widening discrepancy in labour market outcomes based on the reputation of graduating colleges and the college major.

Higher education has been reported to have nonlinear effects on economic growth in ASEAN5 nations (Thailand, Indonesia, Malaysia, Singapore, and the Philippines) between 2000 to 2018. Various education indicators have been used to analyse the effects of education on economic growth. Studies have verified the nonlinear impacts of government spending per 
SCIENCES

Vol. 11, No. 1, 2022, E-ISSN: 2226-3624 @ 2022 HRMARS

tertiary student on economic development. It was found that the influence does not necessarily in accordance with the rule of diminishing returns. Second, the data show that a rise in graduate unemployment can either positively or negatively influence on economic growth. Finally, higher enrolment in secondary and higher education can help ASEAN-5 prosper economically. As a result, Maneejuk and Yamaka (2021) posited that while secondary enrolment rates have a positive impact on economic growth, higher education is critical for future sustainability and growth.

In Indonesia, Trisnaningsih et. al (2020) examined graduate attributes that might boost the uptake of higher education graduates into the Indonesian labour market. It was found that graduates' abilities had a significant direct impact on their ability to obtain work after graduation. Furthermore, the researchers believe that networking and professional certifications will increase higher education graduates' uptake in Indonesia, as sought by stakeholders, as well as their capacity to compete on a global or international work climate. Peng, Yip and Law (2019), study was conducted in Hong Kong, which face one of the world's most critical economic inequality despite the high increase in higher education over the previous two decades. The findings demonstrate that the non-degree tertiary education produces the same return across varying earning distribution. This finding implies that lowearners no longer gain more from such an education than higher-earners, and that the education's equalising impact on earnings has vanished

Choi, Choi and Son (2021) examined the long-term impacts faced by South Korean college graduates in the labour market before, during, and after the 1997-1998 Asian financial crisis. In Korean society, men and women are confronted with difference choices and limitations when making decisions about job, family, and household finances. The study reported that the impacts of the recession are diverse across gender. For more than 12 years after graduation, male participants endure a significant and sustained decline in employment and wages. Meanwhile, the effect of the recession in the labour market is more subtle for women. This is because even those who graduated in a robust economy have relatively smaller labour force engagement due to family commitment. In this regard, as female participants mostly have smaller employment opportunities and earnings right after graduation, the negative recession effect is negligible within 2 years. The limited job opportunities in earlier in their career has led to increased childbirth and higher fertility.

A Malaysian study by Aman (2021) examined the long-term viability of ImS in Malaysian higher education institutions, specifically for graduates' employability. The study found that LmS might boost future graduates' technical and soft skills, increasing their employability in the Global Business Services market. On the other hand, infrastructure, rewards, and incentives and system dependability are hindrance that must be addressed. Meanwhile, a study by Zhang and Wang (2020) reported that China's higher education has evolved into a mutual choice employment system, moving away from the conventional unified allocation method. In this regard, the employment of university graduates in China varies substantially by area. Different macro and micro variables, as well as direct and indirect influences on employment, affect science and engineering, economics, and management graduates. The distribution of jobs in science and technology is strongly linked to regional GDP, however, distribution of jobs in economics and management indicate regional stickiness. 
SCIENCES

Vol. 11, No. 1, 2022, E-ISSN: 2226-3624 @ 2022 HRMARS

\section{Knowledge, Experience and Skills Development}

The Chinese government introduced several initiatives to promote entrepreneurship activities among university students and graduates. Many researchers have conducted studies and proved this measure has a positive effect in overcoming unemployment among graduates. Entrepreneurial education and policy, according to Li and Islam (2021), have a positive, direct influence on entrepreneurial self-efficacy and intention, respectively. Higher Education Expansion (HEE) study is an approach that examines the influence of university and college education on entrepreneurship in China. The findings reflect that the status of graduates have a positive impact on entrepreneurship education. This means that people who have completed higher education are more likely to have participated in an entrepreneurship programme or programmes that encourage them to start a new business. (Zhou, Li \& Shahzad, 2021). However, Huang, Tani and Zhu (2021), stated that people with higher education are generally less likely to become an entrepreneur. Therefore, graduates are encouraged to be involved in entrepreneurship because they can own large business partnerships and earn more money in the future.

According to Lu, Song and Pan (2021), Chinese higher education institutions have conducted a slew of excellent programmes to encourage students to start businesses. Entrepreneurial attitude, subjective norms, and entrepreneurial self-efficacy are all favourably influenced by university entrepreneurship support. Hence, such support increases students' intention to be entrepreneurs. This reflects the importance to provide pupils with entrepreneurial education (Yuan, Wang and Mao 2020) and assist students in broadening their horizons in graduate work. Graduate entrepreneurs had higher career satisfaction than graduate employees although they have more work commitments than graduate workers. Entrepreneurship also has been one of the options for combating the high unemployment rate among Malaysian graduates (Kamaruddin, Mauzud \& Zin, 2019). Despite the different initiatives and policies implemented, statistics revealed that graduate involvement in this subject is still poor. According to Huang, Tani and Zhu (2021), those with a higher education are less likely to become entrepreneurs. Therefore, graduates are encouraged to be involved in entrepreneurship because they can own large business partnerships and earn more money in the future.

Students need internships to improve their employability and long-term growth. Chen and Gan (2021) evaluated the effectiveness of the Internship Promotion Programme (IPP) in Zhejiang Province, China, in improving graduates' employability. It was reported that students enrolled in IPP have higher competency to conduct critical business activities and subsequently, more appealing to employers. The study concluded that IPP improves students' employability and increase higher education, quality resulting in long-term growth. HEls play a role in improving graduates' knowledge, skills, and competencies (KSC), and ultimately, their employability. A study by Herlambang et.al, (2021) involving Indonesian medical students found that the students urged politicians to establish proper rules to improve students' KSC and employability. In the meantime, Al Shaikh, Camara and Baruch (2020) reported that High-performance human resource practises (HPHRPs) significantly influence career achievement. At the same time, research performance of faculty members at Saudi Arabian public institutions mediates the relationship between these constructs.

The growth of technological education has raised several critical issues regarding student employability. There is a growing understanding of social responsibility among universities and many education institutions strive to establish effective sustainability strategies (Huang \& Hsiesh, 2020). This has led to the introduction of approaches in technology education like 
SCIENCES

Vol. 11, No. 1, 2022, E-ISSN: 2226-3624 @ 2022 HRMARS

Course-Professionalization Technology Assessment (CPTA), Information Immediacy Usability Openness Technological Feature (IIUOTF), Concurrent Usage Convenience Technological Feature (CUCTF), and Course-evaluation Technology Analysis System (CTAS) to empower critical determinants of students' employability like Communication Expression Ability (CEA), Problem-solving Ability (PSA), Self-control Capability (SCC), Active Attitude and Ambition (AAA). Four factors, economic status, education level, employment level and gender ratio have been found to impact international vocational qualification and certification (IVQC). In this regard, employment level is deemed as the most significant contributor while education level has the smallest influence (Bai et. al., 2020). Thus, IVQC is more common into areas that are developed, has high employment rates and male dominated. IVQC should be promoted through progressive social progress and global development.

The fast growth of Taiwan's higher education institutions has had an influence on college graduates' unemployment rate. In the last six years, the unemployment rate for college or university diploma graduates was approximately 5\%. A study by Hsieh and Usak (2020) recommended a systematic development of three effective teachers' abilities, which are Cooperative Relationship Competency (CRS), Interflow Communication Abilities (ICA), and Teaching Resource Distribution (TRD) of Resource Satisfaction Competency (RSC) to improve graduate employability, employment rate and the value higher education in Taiwan. Likewise, Baek, Cho and Kim (2019) analysed the impact of convergence education as well as academic performance on employability using employability-course matched data on graduates from a college of engineering in Korea from 2008 to 2015. The results indicated that the greater the percentage of business administration or economics classes taken, as well as the total GPA and involvement in study abroad programmes, the more favourable the influence on getting a job was.

Universities offering regular courses, education programs, and individual activities on human rights, diversity, and corporate responsibilities are concerned with education for sustainable development. A study by Baek and Cho (2018) empirically investigated the righteous circle between extracurricular activities in education and labour market performance. The study used Education-Career match data from 15,180 graduates of a Confucian-based university from 2008 to 2015 . The study indicates that grades and humanities-based extracurricular activities have a good impact on employment. Hence, universities should develop an educational system which integrates expertise, human growth, equality, and human rights, and businesses should develop a specific employment guideline to identify the intangible trait of job seekers to maintain the circle to education and social and economic activities.

\section{Discussion}

The aim of this paper is to explore the problematization between higher education and unemployment in Asian countries through a systematic literature review. Inaddition, solution measures for the problem recognised are also discussed. Although many previous studies have discussed the problem of unemployment among higher education graduates, this research is a more recent finding and focuses on Asian countries as a whole using the method of systematic literature review. This research starts by identifying the main issues related to unemployment among graduates from higher education. In this sense, given the data previously reported, there are two central thoughts that would be interesting to investigate. First, graduate expectations: there is a form of misalignment between job seekers and their future employers on what is expected after getting the position. There is also a set of knowledge and skills that employers acquire from graduates to fulfil the vacancy but do not 
SCIENCES

Vol. 11, No. 1, 2022, E-ISSN: 2226-3624 @ 2022 HRMARS

have. Students expect that after graduation they will have the opportunity to get a good job accompanied by a high salary. However, the rapid development of higher education has resulted in a staggering number of graduates. The competition for jobs is becoming increasingly challenging. When the supply of labour exceeds the demand for labour, the rate of wages will decrease. This economic theory is in line with the findings of (Chen et. al 2021; Lee 2021; Khan et. al, 2021), who found that Taiwan's graduate wage rates in the 2000s were lower than in the 1990s. Unsatisfactory wage rates cause the younger generation to feel that investing in education is not something that benefits them. Higher education does not guarantee a better life in the future if job vacancies are not aligned with the expansion of education. As a result of having difficulty getting a job after graduation, students acquire support programs from the university. Students need a guide to improve their soft skills, leadership skills, skills in the use of technology need to be disclosed to boost the marketability of university graduates ( $\mathrm{Na}$ et. al., 2021; Yoon et.al., 2020; Lim et.al., 2018).

Next factors which are related to the unemployment problem are the job market and economic conditions in Asia. Job creation is a major concern of every government to ensure job opportunities are created. This is because the development and growth of a country is significantly influenced by the quality and quantity of the human resources. According to the Solow neoclassical model by Solow (1990), growth in output is factored partially by the labour force quantity. It is vital to know that the number of graduates represents high-quality human resources that will boost the economy's output. Therefore, Maneejuk et al (2021), conclude that graduate enrolment rates positively affect economic growth. Economic growth is stagnant, by uncertainty regarding economic, political, and social. For example, the worldwide coronavirus pandemic curtailed economic activity, forcing many firms to close and restricting human movement and trade. This pandemic has caused many people to lose their jobs while graduates looking for work continue to remain unemployed. The mismatch between supply and demand can result in significant imbalances that have far-reaching consequences for both individuals and the nation Zheng et al (2021); Wang et al (2020). There are also long-term effects in the labour market before, during, and after the 1997-1998 Asian financial crisis to countries involved.

Based on the systematic literature review that has been conducted, in addition to explaining the factors of unemployment among graduates, previous researchers also suggested steps that can be taken to overcome the problem under the theme of knowledge, experience, and skills. Most researchers suggest entrepreneurship as one of the best solutions to overcome the problem of unemployment among graduates in Asian (Li et al., 2021; Zhou et al., 2021; Lu et al. 2021; Mei et al., 2020; Lu et al., 2021; Yuan et al., 2020). One of the best ways to reduce the high unemployment rate among graduates is to start their own business (Kamaruddin et al., 2019). University entrepreneurship support programmes positively affects entrepreneurial attitude, entrepreneurial self-efficacy and entrepreneurial intention for more students to become entrepreneurs. Graduate entrepreneurs also had higher career satisfaction than graduate employees. In conclusion, exposure to entrepreneurial knowledge and skills should be continued and improved. It enables graduates to generate work for themselves rather than relying on limited job opportunities.

Furthermore, internships also help students enhance their employability. As a result, students with internship experience demonstrated greater ability to perform important workplace tasks, making them more appealing to employers (Chen \& Gan, 2021). One of the most in-demand abilities currently needed is the ability to use information technology. 
SCIENCES

Vol. 11, No. 1, 2022, E-ISSN: 2226-3624 @ 2022 HRMARS

Graduates must be equipped with the most up-to-date platforms and software in order to make themselves more employable (Huang and Hsiesh, 2020; Bai et al., 2020). Meanwhile, the students also should not depend entirely on the university and the formal education system for their personal development. They have to be more proactive and take the initiative to acquire essential skills. Involvement in extracurricular activities is an excellent outlet for building self-confidence and soft skills (Baek \& Cho, 2018).

\section{Conclusion}

Higher education institutions (HEIs) play a critical role in producing knowledgeable and skilled citizens. The rapid development of HEls is a positive indicator of economic growth and national development. Besides, higher education also will indirectly improve one's quality of life due to getting a better job and higher wages. However, statistics in Asian countries show an increase in the number of graduates followed by an increase in the number of unemployed graduates. The imbalance between an increasing number of graduates and fewer job opportunities is atrocious for the future of the country and economic growth. This situation also leads to a waste of resources. Based on the analysis of the literature review that has been conducted, there are three main factors of unemployment among graduates of HEls in Asian countries, which are graduate expectations and knowledge, experience and skills development, and job market and economics. Most of the articles revealed that experience and skills development is the main factor that led to unemployment among HEls graduates, followed by the job market and economics.

There is a distinct gap between employee, employer, and academic expectations. While they both want graduates to be creative, critical thinkers, and capable of addressing technical problems, they disagree regarding institution's roles in producing such graduates. Employers claimed that the graduates were not well-trained, despite academics' claims that their graduates are highly skilled. Thus, universities and the industry must re-examine and readjust their expectations to bridge the gap. Another suggestion is that institutions revise their IT curricula on a yearly basis to stay up with the field's fast-changing nature. Simultaneously, they must strike a balance between the requirement to produce productive employees and the overarching purpose of training students to be moral, ethical, and responsible citizens. Universities should also re-evaluate their programmes to improve creativity and critical thinking to ensure students could think creatively and critically. Lastly, problem-based learning should be used as much as possible to stimulate creativity and critical thinking. It is also important to bear in mind that employers would have different expectations and demands.

Employers constantly face intense pressure to innovate and adapt in a short amount of time. Given the time-consuming procedure for academics to refresh their own expertise and then adjust the curriculum and courses, it would be absurd to expect universities to produce graduates who fulfil every employer's demands. Realistically, universities can focus on instilling more broad abilities and aptitudes in its students, and the industry refines the specialised knowledge and skills necessary through on-the-job training. Meanwhile, students' personal growth should not be solely dependent on the institution and formal education system. They must be more proactive in acquiring the required competencies.

In recent years, starting a business has become an attractive option for graduates instead of waiting for job offers to materialise. Students' engagement in entrepreneurship is often inspired successful and enterprising young entrepreneurs in the field. This situation shows that to increase graduate employability, the primary players (graduates, 
SCIENCES

Vol. 11, No. 1, 2022, E-ISSN: 2226-3624 @ 2022 HRMARS

academics/universities, employers, and the government) must collaborate. Without engagement with companies, universities cannot guarantee employment for their graduates. In the meantime, students must try to learn and gain the necessary information and abilities in a supportive atmosphere and the government should increase efforts to enforce policy framework and economic conditions that could support job seekers. The rapid development of higher education must also be in line with the increase in economic growth. A favourable economic environment can create more employment opportunities. This could make people feel that investing in higher education is something that is profitable and not detrimental towards a better life.

\section{Conflicts of Interest}

The authors declare that they have no conflicts of interest to report regarding the present study.

\section{References}

Mubarak, Al S. A., Da Camara, N., Baruch, Y. (2020). The Impact of High- Performance Human Resource Practices on The Research Performance and Career Success of Academics in Saudi Arabia. Career Development International, 25(6), 671- 690.

Aman, A. (2021). Sustainability of Impact Sourcing Initiatives in Higher Education For Graduates' Employability. Sustainability (Switzerland) 13(1), 1-11.

Baek, W., Cho, J. (2018). Identifying the Virtuous Circle of Humanity Education and PostGraduate Employment: Evidence from A Confucian Country. Sustainability (Switzerland), 10(1), 1-15.

Baek, W., Cho, J., Kim, Y. B. (2019). Convergence in Education and Employment of Engineering Students: Korean Evidence. Inzinerine Ekonomika - Engineering Economics, 30 (1), 5968.

Bai, L., Bao, T., Zhang, K., Shi, H., Wang, Z., Bai, S. (2020). Influencing Factors for The Promotion of International Vocational Qualification and Certification: Evidence From International Project Manager Professionals in China. Sustainability (Switzerland), 12 (5), 1-20.

Braun, V., \& Clarke, V. (2006). Using Thematic Analysis in Psychology. Qualitative Research in Psychology, 3(2), 77-101

Chen, C. L., Chen, L. C. (2021). The Impact of Higher Education Expansion on The Educational Wage Premium in Taiwan: 1985 to 2015. International Journal of Financial Studies, 9 (3), 1-12.

Chen, Y., Gan, N. (2021). Sustainable Development of Employability of University Students Based on Participation in The Internship Promotion Programme of Zhejiang Province. Sustainability (Switzerland), 13(23), 1-14.

Choi, J., Bae, H. (2020). Changes In Early Labor Market Outcomes Among Young College Graduates in South Korea. Annals Of the American Academy of Political and Social Science 688, (1), 115-136.

Herlambang, H., Fitri, A. D., Mukminin, A., Muhaimin, M., Hidayat, M., Elfiani, E., Shafira, N.N.A., Puspasari, A., Tarawifa, S., Salam, A.A., Yaakob, M.F.M., Habibi, A. (2021). Quality assurance for sustainable higher education: Structural equation modeling. (Switzerland), 13(9), 1-14.

Huang, B., Tani, M., Zhu, Y. (2021). Does Higher Education Make You More Entrepreneurial? Causal Evidence from China. Journal Of Business Research, 135, 543-558. 
SCIENCES

Vol. 11, No. 1, 2022, E-ISSN: 2226-3624 @ 2022 HRMARS

Huang, Y.-M., Hsieh, M.-Y. (2020). Interdisciplinary Research on Students' Employability in Technology Education to Advance Higher Education Enrolment Sustainability. Sustainability (Switzerland), 12(5), 1-16.

Hsieh, M.-Y., Usak, M. (2020). High Education Radical Transformation Era: How Teachers' Competency Can Enhance the Students' Employability? Revista De Cercetare Si Interventie Sociala, 68, 95-112.

Kamaruddin, S. H., Mauzud, S. M., Zin, N. A. M. (2019). Exploring The Ecological Assets of Tunas Mekar Project's Graduate Entrepreneurs. Geografia Malaysian Journal of Society \& Space, 15(4), 288-303.

International Labour Organization (ILO). (2019). Global Employment Trends for Youth 2020: Asia and The Pacific. 76-95.

Khan, J., Hemsley-Brown, J. (2021). Student Satisfaction: The Role of Expectations In Mitigating The Pain of Paying Fees. Journal Of Marketing for Higher Education, 1-24.

KERI (Korea Economic Research Institute). 2020. Youth Unemployment Rate, OECD 4.4\%P Decrease Over 10 Years, Korea 0.9\% Increase." Press Release. Available online: http://www.keri.org/web/www/news (Accessed on 15 Jan 2021).

Lee, Y.-C. (2021). Replacing Work with Study: A Sustainable Development Strategy for Economically or Culturally Disadvantaged Students. Sustainability (Switzerland), 13(17), 1-14.

Li, Z., Islam, A. Y. M. A. (2021). Entrepreneurial Intention in Higher Vocational Education: An Empirically Based Model with Implications for The Entrepreneurial Community. SAGE Open 11(4), 1-14.

Lim, J. Y., Lee, Y. M. (2018). Exit Duration and Unemployment Determinants for Korean Graduates. Journal For Labour Market Research, 53 (1),1-14.

Lu, G., Song, Y., Pan, B. (2021). How University Entrepreneurship Support Affects College Students' Entrepreneurial Intentions: An Empirical Analysis from China. Sustainability (Switzerland), 13(6),1-25.

Maneejuk, P., Yamaka, W. (2021). How University Entrepreneurship Support Affects College Students' Entrepreneurial Intentions: An Empirical Analysis from China. Sustainability (Switzerland), 13(6), 1-25.

Mei, H., Lee, C.-H., Xiang, Y. (2020). Entrepreneurship Education and Students' Entrepreneurial Intention in Higher Education. Education Sciences 10, (9), 1-18.

$\mathrm{Na}, \mathrm{T}$. K., Lee, S. H. (2021). A Survey-Based Education Needs Analysis of Employment Support Programs for Hospitality Undergraduate Students Social Sciences - Basel, 10(3), 103-117.

Moher, D., Liberati, A., Tetzlaff, J., Altman, D. (2009). Preferred Reporting Items for Systematic Reviews and Meta Analyses: The PRISMA Statement. Plos Medicine, 6,1- 6.

Solow, R. (1990). The Labor Market as A Social Institution. 268-84.

Trisnaningsih, S., Sutrisno, S., Permatasari, Y., Hendra, F. H., Sulistyowati, E. (2020). Contingency Model to Increase the Uptake of Higher Education Graduates in The Job Market. Journal Of Asian Finance Economics and Business, 7(4), 197-203.

UNESCO. (2022). http://data.uis.Unesco.org/Enrollment By Level Of Education/ Enrolment in Tertiary Education.

Wang, W., Dong, Y., Bai, Y., Luo, R., Zhang, L., Liu, C., Hagist, S. (2020). Returns To Education in Different Job Locations for Off-Farm Wage Employment: Evidence From

China. Sustainability (Switzerland), 12(2), 1-14. 


\section{SCIENCES}

Vol. 11, No. 1, 2022, E-ISSN: 2226-3624 ㄷ 2022 HRMARS

Yoon, J., Park, S., Kim, D.-J. (2020). Assessing The Effects of Higher-Education Factors on The Job Satisfaction of Engineering Graduates in Korea. Sustainability (Switzerland), 12(8), 1-10.

Yuan, C.-H., Wang, D., Mao, C., Wu, F. (2020). An Empirical Comparison of Graduate Entrepreneurs And Graduate Employees Based on Graduate Entrepreneurship Education and Career Development. Sustainability (Switzerland),12 (4), 1-15.

Zhang, Q. W., Wang, X. R. (2020). Factors Influencing Employment Rate and Mobility Of Science And Engineering and Economics and Management Graduates in Northeast China: An Examination. SAGE Open, 10 (2), 1-15.

Zheng, Y. Q., Zhang, X. Q., Zhu, Y. (2021). Overeducation, Major Mismatch, And Return to Higher Education Tiers: Evidence from Novel Data Source of a Major Online Recruitment Platform in China. China Economic Review, 66, 1-14.

Zhou, Y. L., Li, H. B., Shahzad, F. (2021). Does College Education Promote Entrepreneurship? Education In China? SAGE Open 11 (3), 1-13. 